\title{
How Do EFL Students Perceive Brainstorming in L2 Writing Classes?
}

\author{
Maryam Shirvani \\ Central Tehran Branch, Islamic Azad University, Tehran, Iran
}

\author{
Reza Porkar \\ Faculty of Foreign Languages, TEFL Department, North Tehran Branch, Islamic Azad University, Tehran, Iran
}

\begin{abstract}
Brainstorming is a valuable pre-writing activity in enabling learners to get started in writing classes. The present qualitative study explored the participants' perceptions regarding the use of the method after experiencing it in online writing classes. The participants were selected based on convenience sampling, and their age range was 19 to 23 . They had participated in private writing classes and volunteered to take part in interviews performed after the course. The interviews were also done virtually via WhatsApp, during which the respondents answered six questions. The analysis of the interviews led the researchers to extract eight significant themes, which were then divided into advantages and disadvantages. The interviewees mentioned idea generation, encouraging new ideas, becoming open-minded, enhancing motivation to write, and creating stronger rapport with classmates as the positive features of brainstorming. The disadvantages consisted of being distracted by too many ideas, being influenced by others' ideas, and accepting ideas expressed by the majority. The study has implications for language teachers, educators, and ELT specialists.
\end{abstract}

Index Terms - brainstorming, L2 writing, online classes, students' perceptions

\section{INTRODUCTION}

Writing is a challenging task, and EFL/ESL learners usually have problems composing essays. Learners must pay attention to several issues during writing, including grammar, mechanics, coherence, and cohesion. Therefore, teaching writing should be an amalgamation of different techniques and strategies used to create a composition. Teachers apply various techniques in writing courses to enhance learners' writing ability, which partially relates to how they view writing. Some prioritize content and idea generation and resort to different classroom practices to teach writing (e.g., Helen, Paul, \& Hellen, 2020; Rahmawati, 2019; Rashtchi, 2007). Some consider grammar and mechanics as essential factors in promoting learners' writing ability. Thus, they focus on practices that draw learners' attention to the writing structures (e.g., Rashtchi \& Mohammadi, 2017; Rashtchi \& Ghandi, 2011). Still, some teachers believe that writing is an excellent practice for stimulating thinking skills (Rashtchi, 2019; Rashtchi \& Aghajanzadeh, 2008; Sheikhy Behdani \& Rashtchi, 2019). One activity that boosts thinking and helps learners write with ease is brainstorming. As a prewriting activity, it has a primary role in developing ideas, and many teachers use it in their classes (e.g., Rashtchi \& Beiki, 2015; Rashtchi \& Porkar, 2020). However, research studies usually focus on the effects of brainstorming in students' writings. What seemed essential to the current study's researchers was to explore EFL learners' views regarding brainstorming and how they perceive its role in advancing writing skills. The present study investigated participants' perceptions regarding brainstorming after practicing the activity in an online writing course.

\section{LITERATURE REVIEW}

The mainstream teacher-centered methods have long been replaced by student-centered educational settings in which learners are held responsible for reflection and the creation of meaning. Brainstorming as a student-centered approach has gained prominence in the twenty-first century due to its role in learner autonomy (Smit, Brabander, \& Martens, 2014).

Brainstorming, which pivots around spontaneous pair or group discussions to nourish creative thinking, lateral thinking, and problem-solving, was coined by Alex Osborn (1963) and has been a bold concept since it enjoys numerous positive attributes. Some defining characteristics of brainstorming include "multiple ways of thinking, breaking old thoughts, associating different concepts, expanding the borders of thoughts, and seeking problem-solving" (Hoing, 2001, as cited in Tsai, Liao, Chang, \& Chen, 2020). In addition, the prohibition of either criticism or even praise of the generated ideas is a distinguishing attribute of brainstorming since praise of an idea attaches negativity to other opinions that are not praised and can be construed as inappropriate. Brainstorming is a cooperative activity, and teachers use it to develop sharing ideas and group activities in their classes. However, it can be applied with even one individual and might cultivate perspective-taking.

Regarding L2 writing and brainstorming, as Rashtchi and Porkar (2020) state: "it facilitates the process of generating ideas and helps organize learners' thoughts to get involved in writing activity" (p. 1). While brainstorming, some 
seemingly impractical thoughts might spark even more valuable ones and add to the richness of the collected ideas. Amoush (2015) investigated the role of brainstorming in EFL learners' writing and showed the effectiveness and priority over traditional teaching methods. It is worth mentioning that this problem-solving mode comes in different types, such as nominal, traditional, and electronic. Usually, brainstorming involves different groups who put forward related ideas to be classified while fulfilling a task. Learners who are engaged in brainstorming encounter various viewpoints by sharing ideas with peers. Brainstorming stimulates their thinking skills and curiosity for looking for new ideas (Amoush, 2015; Asundi \& Rao, 2018; Ryoo, Molfese, \& Brown, 2018).

In traditional brainstorming (TBS), there is verbal intragroup interaction. Members of each group are supposed to share thoughts orally by going through different steps. First, groups of three to ten from diverse backgrounds are formed. Second, the problem, task, or topic is presented to the learners. Then, in a non-judgmental atmosphere, ideas are generated, a step also known as the divergent phase. Finally, the generated ideas are discussed and prioritized in what is called the convergent phase. Although advantageous, there is the risk that not all members take an active role in the process due to laziness or shyness. As a result, there could be insufficient ideas regarding the imbalanced number of the members and produced thoughts (Al-Samarraie \& Hurmuzan, 2017). In Nominal brainstorming, every member in each group is held responsible for idea generation via communicating with other group members (Henningsen \& Henningsen, 2013). Nominal brainstorming can yield a more significant number of ideas. However, since its role as the technique that lets the learners produce quality thoughts individually has remained unclear, its efficacy has been questioned (Sutton \& Arnold, 2013). As another type of brainstorming, electronic brainstorming has been introduced in recent years to compensate for nominal brainstorming's defects. Through electronic brainstorming, learners are free to use any electric forms of obtaining data, such as the Internet (Baruah \& Paulus, 2016). In some contexts, electronic brainstorming might be considered more practical since students could generate more ideas than other varieties of brainstorming. However, there is no consensus on the most effective form of brainstorming. Context of instruction, the field of study, and discipline are decisive factors in verifying the practicality of brainstorming (Brandies \& Dotzauer, 2016).

Regarding what is mentioned earlier, different fields of study such as business, psychology, and languages have employed various brainstorming modes in educational processes, and the results were rewarding. For instance, in a study on a civic course, the researchers reported a rise in the participants' performance, more creative learning, improved interactions among peers, and more meaningful activities due to employing brainstorming activities (Matto, McCartney, Bennion, \& Simpson 2017). In a 2014 review of the effectiveness of brainstorming in five disciplines of business, language, education, industry, and psychology and 42 studies, especially electronic brainstorming, were reported to be the most beneficial, particularly in decreasing social stress and enhancing learners' creativity.

However, one danger of the activity is an "increase in cognitive load for individuals who lack knowledge and communication skills to participate in shared decision-making, which may limit the quality of the produced solutions" (Johnson \& D'Lauro, 2017, p. 4). On the other hand, some learners might be more productive while working on their own. In the field of L2 learning, a study comparing the effects of mobile-assisted BS, wordle-assisted BS, and cooperative BS showed that wordle-assisted BS could be more advantageous in practicing argumentative essays (Rashtchi, \& Porkar, 2020).

Mastery in writing in a second language has always been a source of worry for learners and educators. The root of the difficulty is the need to focus simultaneously on lower and higher-order thinking skills to come across ideas worthy of writing. As Luchini (2010) puts it, "the different cognitive and linguistic characteristics involved in the writing ability make it a difficult task for students to learn" (p. 84). Besides, as the primary trend in teaching writing is to shift from product-based to process-based writing skills (Alodwan \& Ibnian, 2014; Cavkaytar, 2010; Hyland, 2016), learners are assumed to receive scaffolding during the different stages of writing. The literature on L2 writing has shown a direct relationship between writing proficiency and writing strategies. Brainstorming is one of the well-known strategies capable of transforming a seemingly tedious task into an enjoyable experience for the learners. This viewpoint is the ground for attaching considerable significance to this form of band or group inventiveness.

Numerous scholars have documented the positive role of brainstorming in L2 writing. For instance, Storch (2005) investigated the role of brainstorming on writing skills and concluded that cooperative writing has the potential to increase not only writing quantity but also quality as the learners could produce more persuasive arguments. The success of brainstorming could be due to solving the most severe challenges learners encounter, that is, idea generation and getting started. As Fang (2013) states, finding worthy thoughts for producing a quality writing paper is of great value. Maghsoudi and Haririan (2013), in their study, pointed to learner autonomy gained through brainstorming while trying to fulfill a writing task. Besides, Khalaf Ibnian (2011) confirmed more beneficial roles of BS in organization strategies and mechanics of writing.

Writing is a vital skill in L2 learning. Yong (2010) believes that writing ability can reflect learners' L2 knowledge. However, the skill is challenging for student writers. The positive point is that the wealth of research on L2 writing has led researchers to invaluable understandings that facilitate writing. For instance, research on L2 writing strategies (e.g., Karim, Maasum, \& Latif, 2018; Machili, Mu, 2005; Papadopoulou \& Kantaridou, 2019; Rashtchi, \& Karami, 2015), classroom practices (e.g., Elola, \& Oskoz, 2017; Everson, 2011; Keck, 2014; Rashtchi, Porkar, \& Ghazi Mir Saeed, 2019), and employing context-based tasks (e.g., Leki, Cumming, \& Silva, 2008; Gebhard \& Harman, 2011 ) are only a 
few to mention. However, learners' perceptions regarding the benefits of employing different classroom practices have not been focused on much. The present study aimed to delve more deeply into the use of brainstorming in L2 writing courses. In doing so, the researchers of the present study formulated the following research question:

RQ: How do Iranian EFL learners perceive the role of brainstorming in writing courses?

\section{METHOD}

\section{A. Participants}

Sixteen EFL learners (six males and ten females) in three intact classes participated in a 20 -session online writing course that employed brainstorming as a pre-writing activity. In each class, there were eight learners: one group consisted of six females and two males, and another group of four females and four males. They were university students aged 19 to 23 who had taken a private writing course. They were studying TEFL or Translation studies in different branches of Islamic Azad University. Their purpose was to improve their writing skills to take academic writing courses in their universities afterward. They had selected the classes according to their life schedules. At the onset of the study, the IELTS General indicated that their English level was B2 or upper intermediate (5.5 - 6).

\section{B. Instruments}

\section{Testing Instrument}

The researchers used an IELTS exam extracted from General IELTS 15 (Test 2) to specify the language proficiency level of the participants before starting the writing program. The test consisted of 19 listening questions, 14 reading questions, and one writing task. The speaking section was excluded due to the participants' time constraints and the problems of the online environment.

\section{Interview}

The researchers used interviews to discover the participants' perceptions regarding BS (Appendix A). They included six open-ended questions. Having prepared the first draft, the researchers consulted with two experts regarding the appropriacy of the content. Then five students with similar characteristics to the study participants reviewed the questions and stated their opinions regarding the choice of vocabulary, appropriacy of the questions, and clarity.

\section{Materials}

The coursebook was The Practical Writer (Bailey \& Powell, 2008). Also, ten topics were selected from 501 Writing Prompts (Appendix B) for practicing writing during the course.

\section{Procedure}

Two online writing classes met twice a week for 20 sessions. The classes took 90 minutes. The course was run through the Adobe Connect platform, which made sharing and group work possible. Also, the teacher created a WhatsApp group to connect the learners and facilitate out of the class interaction.

In each session, first, the teacher introduced the topic of the day and asked the learners to think about it individually. They had ten minutes to check the Internet or any sources to get ideas (individual brainstorming). The teacher also wrote some keywords on the screen and asked the learners to express their opinions that were boarded electronically. Then, in each study group, the members were put in two groups of four students to express their ideas and share them with group members (group brainstorming). The participants were encouraged to take notes during discussions. After brainstorming, the participants were required to review their notes, ask for clarification, share ideas, and discuss issues with their classmates. Brainstorming took about half an hour each session. However, the learners used the WhatsApp group to share ideas and negotiate with classmates regarding the ideas suggested during the class while writing their essays.

The participants were supposed to write a five-paragraph essay after the class and submit it to the teacher, who was one of the researchers, via e-mails. The writings were corrected by the teacher and e-mailed to the learners. The teacher extracted the common mistakes and explained them in the subsequent session. Each session was also devoted to teaching the coursebook, including grammar, style and mechanics, and coherence.

After the treatment, the participants took part in the online interview sessions via WhatsApp. The teacher explained the purpose before the interview sessions. She clarified that participation was voluntary, and the learners were free to refrain. However, all participants proclaimed their satisfaction in answering the questions. The interviews were run by one of the researchers and took about ten minutes for each participant.

\section{RESUlTS}

The participants' responses regarding the efficacy of brainstorming in writing urged the researchers to divide the main themes extracted from the responses into two categories of advantages and disadvantages of brainstorming. The responses indicated mixed opinions of the participants, although the tendency was much more towards positive attitudes, and the participants' optimistic ideas outweighed the undesirable ones. The participants regarded group brainstorming 
as more of help than the individual one. This finding is congruent with a similar study by Omidvar and Abedianpour (2018), in which the tendency was to group brainstorming.

Concerning the classification of the results, the advantages had five main themes: a) idea generation, b) encouraging new ideas, c) becoming open-minded, d) motivating learners to write, and e) creating stronger rapport with classmates. The disadvantages consisted of a) being distracted by too many ideas, b) being influenced by others' ideas, and c) accepting ideas expressed by the majority.

\section{A. Advantages of $B S$}

Idea Generation: Almost all the participants mentioned the contribution of brainstorming to generating ideas. One problem with writing is that learners do not know what to write. The respondents mentioned that searching the Internet, discussing with their classmates, and sharing ideas were helpful in the writing process. One of the participants mentioned:

Sometimes I felt as if I was totally out of ideas, and this brainstorming thing really pushed me forward.

Encouraging New Ideas: The second category refers to the role of BS in writing. The participants felt that the technique encouraged them to start writing by and providing them with ideas. Most participants mentioned that brainstorming directed their thoughts and gave meaning to the wild or dispersed ideas in their minds. It could help them organize their thoughts and prevent shifting from one issue to the other. Most of the learners mentioned that brainstorming gave them the courage to share their ideas and oppose others' viewpoints. It enhanced their decisionmaking abilities by urging them to select from the ideas proposed during group discussions. The following are some extracts from the interviewees' responses:

"Brainstorming pushed me to talk about my ideas and not worry about being criticized or objected because I felt I was free to criticize others, as well."

"I think I could select the best ideas with a higher speed than the beginning of the course."

"Brainstorming gave direction to my wild ideas and shaped them. Organizing my ideas became easier."

\section{Becoming Open-minded}

The classes helped learners listen to others' viewpoints, express their opinions, and provide reasons for their standpoints. By equipping learners to share ideas (which most of the time continued in the WhatsApp group), the learners tried to challenge others' perspectives, clarify their positions, and convince classmates. They valued the policy of tolerance among the class members and the teacher and appreciated teachers' attitude, who welcomed every thought. The following are extracts from what the participants mentioned:

"I enjoyed the classes because they were not boring. Classroom discussions improved my speaking, too. I tried to look for words to talk about my opinions."

"Brainstorming taught me to listen to others, evaluate what they said, and give reasons when I did not agree with [ideas]."

"The classes gave me the brevity to express my ideas and disapprove others when I did not like them."

Motivating Learners: Another classification of the benefits of brainstorming mentioned by the participants was motivating them to write. The learners believed that the activity lessened their fear of writing. They could focus on the content and free themselves from excessive tendency to "write perfectly from the very beginning," as mentioned by a participant. The learners believed too much focus on grammar impeded the process of writing. They believed:

"Writing seems much easier for me after taking part in the classes. I did not like writing at all. It was the least favorable language skill for me."

"Having ideas helps me to jot down things and feel less stressed about how to start."

"I learned to put ideas down and then correct my writing by drafting and revising."

Creating Stronger Rapport with Classmates: The participants unanimously agreed that brainstorming could establish a friendly relationship among the class members. They felt close to each other and cooperated in the writing process. They thought working in groups created empathy and prepared them for working together to solve a problem. The following are the interviewees' perceptions:

"Brainstorming fostered a friendly atmosphere in the classroom; exchanging ideas helped us to work together."

"Brainstorming helped me to feel responsible for my friends' learning."

"The friendly relationships in the classes changed my mood. I was under pressure due to several reasons caused by the Pandemic. But working together and talking to the classmates were a release."

\section{B. Disadvantageous of Brainstorming}

Analyzing the respondents' answers to the interview questions helped the researchers extricate the following negative points regarding $\mathrm{BS}$.

Being Distracted by Too Many Ideas: Although beneficial, brainstorming is not without downsides. In large groups, brainstormers may come up with too many ideas, making it challenging to choose the quality thoughts from the pool of ideas. In this study, some participants mentioned that they found it hard to make up their minds on selecting the best view from time to time. One of the participants stated: 
"With too many ideas, I didn't know where to start. Sometimes, it took me a lot of time to make up my mind and which position to take."

Another student blamed:

"Sometimes brainstorming was confusing. Sometimes it was not easy to organize what you heard. Sometimes I felt everyone was right in one way or another, which made writing difficult."

Being Influenced by Others' Ideas: Brainstorming can be done through different tools and technological instruments. However, the individuality of the brainstormers might be ignored, and some participants' thoughts could be discarded or overshadowed by other participants. Two of the interviewees mentioned that they did not have a good learning experience since they felt either ignored or found themselves accepting ideas. They did not truly believe in them. They sometimes found themselves inferior to others because they had to change their ideas under the influence of others. One of the participants mentioned:

"I did not like BS because the classmates objected [to] my ideas. I had to modify my viewpoints and think like others in the group. Sometimes, I felt I am self-censoring myself."

\section{Accepting Ideas Expressed by the Majority}

One of the participants complained about feeling the pressure of accepting the opinions of other group members. She stated that although she did not want to do so, she found it challenging to be different. This condition led her to accept the ideas expressed by the majority. Another learner reported her dissatisfaction with intra-group criticism, and consequently, she refrained from sharing thoughts. Another respondent mentioned that he had to modify his ideas although he was not entirely satisfied to do so."

"Sometimes, I felt that I had to change my ideas, though I did not like it."

"There was an unconscious feeling in me to be appraised by others. So, I tried to say something to be pleased. Of course, not always, sometimes."

\section{DISCUSSION}

The interview results indicated that most of the participants were positive toward using brainstorming in writing classes. The interviewees indicated that brainstorming could help them generate ideas. This assertion supports schema theory, prioritizing activating learners' background knowledge and enhancing writing (e.g., Qin, 2016; Sun, 2014).

In addition, the respondents' views clarify that brainstorming can cultivate higher-order thinking skills (e.g., openmindedness, problem-solving, inferencing meaning). This finding indicates that BS can be used to teach critical thinking skills and help educators employ them in different learning activities. This finding aligns with what Rashtchi and Sadraeimanesh (2011) found regarding the role of debate in promoting critical thinking skills.

The interviewees' viewpoints conform to the research findings regarding the efficacy of brainstorming for developing learners' writing performance (e.g., Khalaf Ibnian, 2011; Manouchehry, Farangi, Fatemi, \& Qaviketf, 2014; Rashtchi \& Beiki, 2015), who found that the activities develop learners' writing performance.

However, the disadvantages mentioned by the learners are worthy of attention. The findings align with Isaksen and Gaulin (2005). They believe that brainstorming may have some threats such as motivation loss, pressure to follow specific ideas, and inhibition. The researchers of the current study recommend teachers be careful while applying brainstorming in their classes. Although it is a student-centered activity, teachers' roles as facilitators and supervisors are highly required.

\section{CONCLUSION}

The present qualitative study explored a group of participants' perceptions regarding the use of brainstorming in writing classes. The interview results directed the researchers to extract five advantages and three disadvantages regarding employing the technique in writing classes. The participants experienced brainstorming in virtual courses. Thus, extending the results to in-person courses should be done cautiously. Besides, the limited number of participants, typical of qualitative studies, does not allow its generalization to other contexts. Since brainstorming is a practical prewriting activity, the researchers suggest additional surveys on its advantages and drawbacks in writing classes. The participants' social background, country of residence, and personality features, which were not considered in the current study, can also affect their perceptions about the technique.

\section{APPENDIX A. INTERVIEW QUESTIONS}

1. What do you think about brainstorming used in your classes at the beginning of each session?

2. Did you find brainstorming helpful? Please explain.

3. Did brainstorming have any drawbacks? Please explain.

4. In what measures did you find brainstorming useful?

5. Do you prefer to have brainstorming in your writing classes in the future? Why or why not?

6. Any additional comments you want to mention about the writing course? 


\section{APPENDIX B. WRITING TOPICS}

1-We all have favorite activities that we enjoy. Write an essay convincing readers to try the activity that you enjoy most.

2-Write an essay convincing readers to break a specific habit that is harmful to their physical, emotional, or financial health.

3-Have you ever traveled to a place that you found very meaningful and rewarding? Write an essay that persuades others to visit this important place.

4- A few decades ago, many families had half a dozen or more children. Nowadays, more and more families are choosing to have only one or two children. Are smaller families better than larger ones? Why or why not? State your position and support it with specific reasons and examples.

5-What is your all-time favorite movie and why? Write an essay persuading readers to watch this film.

6-Have you ever made a change that improved your life or the lives of others? Write an essay that convinces readers to make a change for the better.

7-You have been asked to write a brochure to attract visitors to your hometown. Write an essay that convinces people to visit the place where you live.

8-Many people believe that honesty is the best policy. In your opinion, is it ever okay to lie? Explain your answer using specific reasons and examples.

9-What would improve your hometown? Write an essay convincing town officials to make a change that would improve your neighborhood.

10-Every year, millions of people visit zoos around the world. But some people believe that zoos are inhumane and that animals should not be kept in captivity. Do you agree? Why or why not? Use specific reasons and examples to support your position.

\section{REFERENCES}

[1] Alodwan, T.A.A., \& Ibnian, S.S.K. (2014). The effect of using the process approach to writing on developing university students' essay writing skills in EFL. Review of Arts and Humanities, 3(2), 139-155.

[2] Al-Samarraie, H., \& Hurmuzan, S. (2017). A review of brainstorming techniques in higher education. Thinking Skills \& Creativity. 27(2018), 78-91. https://doi.org/10.1016/j.tsc.2017.12.002

[3] Amoush, K. H. (2015). The impact of employing brainstorming strategy on improving writing performance of English major students at Balqa Applied University in Jordan. Journal of Education \& Practice, 6(35), 88-92. Retrieved June 25, 2020, from http://iiste.org/Journals/index.php/JEP

[4] Asundi, S., \& Rao, D. (2018). A system pedagogy and a novel brainstorming approach to initiate Pico/Nano/Micro-Satellite (PNM Sat) engineering research development at academic institution in India. Journal of Engineering Education Transformations, 32(1), 103-114. https://doi.org/10.18260/1-2-29708

[5] Bailey, E. P., \& Powell, P. A. (2008). The practical writer. Thomson Higher Education.

[6] Baruah, J., \& Paulus, P.B. (2016). The role of time and category relatedness in electronic brainstorming. Small Group Research, 47(3), 333-342. https://doi.org/10.1177/1046496416642296

[7] Brandies, A., \& Dotzauer, M. (2016). Transdisciplinary approaches in practice-oriented research projects as combination of method and methodology: Consideration of need as well as requirement analysis and integration. Swiss Inter-and Transdisciplinarity, 11(72), 2-22. https://doi.org/10.13140/RG.2.2.11441.99683

[8] Cavkaytar, S. (2010). Benefitting from writing process method to improve written expression skills in primary education. The Journal of International Social Research, 3(10), 133-139. Retrieved June 25, 2020, from http://www.sosyalarastirmalar.com/cilt3/sayi10pdf/cavkaytar_serap.pdf

[9] Elola, I., \&Oskoz, A. (2017). Writing with 21st century social tools in the L2 classroom: New literacies, genres, and writing practices. Journal of Second Language Writing, 36, 52-60. https://doi.org/10.1016/j.jslw.2017.04.002

[10] Everson, M. E. (2011). Best practices in teaching logographic and non-Roman writing systems to L2 learners. Annual Review of Applied Linguistics, 31, 249-274. https://doi.org/10.1017/S0267190511000171

[11] Fang, N. (2013). Increasing high school students' interest in STEM education through collaborative brainstorming with Yo-Yos Journal of STEM Education: Innovations \& Research, 14(4), 8-14. Retrieved March 25, 2020 from https://www.jstem.org/jstem/index.php/JSTEM/article/view/1814/1560

[12] 501 Writing prompts. (2003). Learning Express.

[13] Gebhard, M., \& Harman, R. (2011). Reconsidering genre theory in K-12 schools: A response to school reforms in the United States. Journal of Second Language Writing, 20(1), 45-55. https://doi.org/10.1016/j.jslw.2010.12.007

[14] Hellen, K.W., Paul, O. A., \& Hellen, I. N. (2020). Use of effective brainstorming technique on standard seven learners' achievement in English composition writing in public primary schools in Kisumu County, Kenya British Journal of Education, 8(1), 32-44. Retrieved March 15, 2021, from www.eajournals.org

[15] Henningsen, D.D., \& Henningsen, M.L.M. (2013). Generating ideas about the uses of brainstorming: Reconsidering the losses and gains of brainstorming groups relative to nominal groups. Southern Communication Journal, 78(1), 42-55. https://doi.org/10.1080/1041794X.2012.717684

[16] Hyland, K. (2016). Teaching and researching writing. Routledge.

[17] Isaksen, S. G., \&Gaulin, J. P. (2005). A reexamination of brainstorming research: Implications for research and practice. Gifted Child Quarterly, 49 (4), 315-329. https://doi.org/10.1177/001698620504900405 
[18] Johnson, R., \& D'Lauro., C. (2017). After brainstorming, groups select an early generated idea as their best idea. Cognitive, Affective, \& Behavioral Neuroscience, 7(4), 297-308. https://doi.org/10.1177/1046496417720285

[19] Karim, S. M. S., Maasum, T. N., \& Latif, H. (2018). Writing strategy instruction to improve writing performance of Bangladeshi EFL learners: A case study. e-Bangi, 15(4). 126-136. Retrieved July 15, 2019, from http://ejournal.ukm.my/ebangi/article/view/28041

[20] Keck, C. (2014). Copying, paraphrasing, and academic writing development: A re-examination of L1 and L2 summarization practices. Journal of Second Language Writing, 25, 4-22. https://doi.org/10.1016/j.jslw.2014.05.005

[21] Khalaf Ibnian, S. (2011). Brainstorming and essay writing in EFL class. Journal of Theory and Practice in Language Studies, l(3), 263-272. https://doi.org/10.4304/tpls.1.3.263-272

[22] Leki, I., Cumming, A., \& Silva, T. (2008). A synthesis of research on second language writing in English. New York: Routledge.

[23] Luchini, P. L. (2010). Evaluating the effectiveness of a complimentary approach to teaching writing skills. International Journal of Language Studies (IJLS), 4(3), 73-92. Retrieved May 15, 2019 from http://www.ijls.net/pages/volume/vol4no3.html

[24] Machili, I., Papadopoulou, I., Kantaridou, Z. (2019). Effect of strategy instruction on EFL students' video-mediated integrated writing performance. Journal of Second Language Writing 48:100708. https://doi.org/10.1016/j.jslw.2019.100708

[25] Maghsoudi, M., \& Haririan, J. (2013). The impact of brainstorming strategies Iranian EFL learners' writing skill regarding their social class status. International Journal of Language \& Linguistics, 1(4-1), 60-67. https://doi.org/ 10.11648/J.IJLL.S.20130101.20

[26] Manouchehry, A., Farangi, M. R., Fatemi, M. A., \& Qaviketf, F. (2014). The effect of two brainstorming strategies on the improvement of Iranian Intermediate EFL learners' writing skill. International Journal of Language Learning and Applied Linguistics World, 6(4). 176-187. Retrieved January 12, 2021 from www.ijllalw.org

[27] Matto, E. C., McCartney, A. R. M., Bennion, E. A., \& Simpson, D. (2017). Teaching civics engagement across the disciplines. American Political Science Association.

[28] Mu, C. (2005). A taxonomy of ESL writing strategies. Proceedings Redesigning Pedagogy: Research, Policy, Practice, 1-10, Singapore.

[29] Omidvari, A. \& Abedianpour, S. (2018). Brainstorming strategy and writing performance: effects and attitudes. Journal of Language Teaching \& Research, 9(5), 1084-1094. http://dx.doi.org/10.17507/jltr.0905.24

[30] Osborn, A. F. (1963). Applied imagination: Principles and procedures of creative thinking (3rd ed.). Charles Scribner's Sons.

[31] Qin, C. L. (2016). A schema-theory based study on the improvement of the college students' English writing. Studies in Literature and Language, 13 (2), 34-42. http://dx.doi.org/10.3968/8753

[32] Rahmawati, F. (2019). Blended learning in an English listening and speaking course: Freshmen's voice and choice. Proceedings of the Third International Conference on Sustainable Innovation 2019 - Humanity, Education \& Social Sciences (IcoSIHESS 2019). https://doi.org/10.2991/icosihess-19.2019.9

[33] Rashtchi, M. (2007). A pathway toward critical thinking through cooperative writing in an English college course in Iran. Near \& Middle Eastern Journal of Research in Education, Volume 2007, Issue 2. https://doi.org/10.5339/nmejre.2007.2.1

[34] Rashtchi, M. (2019). Scaffolding argumentative essay writing via reader-response approach: A case study. Asian-Pacific Journal of Second \& Foreign Language Education, 4(12), 743-788. https://doi/10.1186/s40862-0919-0078-2

[35] Rashtchi, M., \& Aghajanzadeh, M. (2008). Comparative critical reading strategy and writing achievement of Iranian EFL learners. Journal of English Language Pedagogy and Practice, 1(2), 117-130. Retrieved May 12, 2019 from http://jal.iaut.ac.ir/

[36] Rashtchi, M., \& Ghandi, M. (2011). Writing revision strategies: Do they enhance writing ability? Man and the Word (Zmogus ir Zodis), 13(3), 67-80. Retrieved July 15, 2014, from https://www.vdu.lt/cris/

[37] Rashtchi, M., \& Sadraeimanesh, F. (2011). Is debate a useful strategy in enhancing the reading comprehension and critical thinking of Iranian EFL learners? Theory and Practice in Language Studies, 1(4), 361-369. https://doi/10.4304/tpls.1.4.361-369

[38] Rashtchi, M., \& Beiki, M. (2015). The effect of teacher-generated cooperative brainstorming versus learner-generated cooperative brainstorming on activating EFL learners' background knowledge in essay writing classes. Indian Journal of Fundamental \& Applied Life Sciences, 5(2), 1218-1227. Retrieved March 20, 2019, from www.cibtech.org/sp.ed/jls/2015/02/jls.htm

[39] Rashtchi, M., \& Mohammadi, M. A. (2017). Teaching lexical bundles to improve academic writing via tasks: Does the type of input matter? Electronic Journal of Foreign Language Teaching, 14(2), 201-219. Retrieved March 20, 2020, from https://eflt.nus.edu.sg/v14n22017/

[40] Rashtchi, M., \& Karami, V. (2015). Adopting a new identity: A technique to improve writing skill, Journal of Innovation in Language Teaching, 8 (1), 146-159. Retrieved March 20, 2021 from http://jrit-nu.org/

[41] Rashtchi, M., Porkar, R., \& Ghazi Mir Saeed, F. (2019). Product-based, process-based, and genre-based instructions in expository writing: Focusing on EFL learners' performance and strategy use. European Journal of Education Studies, 6(6), 115-136. http://dx.doi.org/10.5281/zenodo.3427842

[42] Rashtchi, M., \& Porkar, P. (2020). Brainstorming revisited: Does technology facilitate argumentative essay writing? Language Teaching Research Quarterly, 18, 1-20. https://doi.org/10.32038/ltrq.2020.18.01

[43] Ryoo, J. H., Molfese, V. J., \& Brown, E. T. (2018). Strategies to encourage mathematics learning in early childhood: Discussions and brainstorming promote stronger performance. Early Education \& Development, 29(4), 603-617. https://doi.org/ 10.1080/10409289.2018.1442095

[44] Sheikhay Behdani, R., \& Rashtchi, R. (2019). Process writing and enhancement of critical thinking ability: Is writing a vehicle or an ingredient of critical thinking? Iranian Journal of Applied Language Studies, 11(1), 181-200. https://doi.org/10.22111/ijals.2019.4937

[45] Smit, K., Brabander, C. J., \& Martens, R. L. (2014). Student-centered and teacher-centered learning environment in prevocational secondary education: Psychological needs and motivation. Scandinavian Journal of Educational Research, 58(6), 695-712. https;//doi.org/10.1080/00313831.2013.821090 
[46] Storch, N. (2005). Collaborative writing: Product, process, and studentse reflections. Journal of Second Language Writing, 14(3) 153-173. https://doi.org/10.1016/j.jslw.2005.05.002

[47] Sun, F. (2014). The application of schema theory in teaching college English writing. Theory and Practice in Language Studies, 4(7), 1476-1482. https://doi.org/10.4304/tpls.4.7.1476-1482

[48] Sutton, S.G., \& Arnold, V. (2013). Focus group methods: Using interactive and nominal groups to explore emerging technology-driven phenomena in accounting and information systems. International Journal of Accounting Information Systems, 14(2), 81-88. https://doi.org/10.5430/jms.v8n4p79

[49] Tsai, N; Liao, F; Chang, L., Chen, C. (2020). Brainstorming flipped classroom approach for improving students' learning performance, motivation, teacher-student interaction and creativity in a civics education class, Thinking Skills \& Creativity 4 (2), 34-38. https://doi.org/10.1016/j.tsc.2020.100747

[50] Yong, M. F. (2010). Collaborative writing features. RELC Journal, 41(1), 18-30. https://doi.org/10.1177/0033688210362610

Maryam Shirvani has her B.A. and M.A. degrees in architecture from Islamic Azad University, Central Tehran Branch, Iran. Her enthusiasm for teaching English motivated her to participate in several teacher training courses and become an English teacher after graduation. She has been teaching English for nine years and has been supervising the English Department of a school in Tehran for four years. She is also a coordinator of online English classes.

Reza Porkar is a Ph.D. candidate in TEFL at Islamic Azad University, North Tehran Branch. He has taught English in different language schools for 11 years. Also, he has been lecturing several courses including English Speaking and Listening, English Language Teaching Methodology, First Language Acquisition, and Second Language Acquisition at Islamic Azad University, North Tehran Branch as a temporary contract instructor since 2011. His areas of interest include English language teaching methodology, augmented reality, and virtual reality in ESL/EFL settings, and theories of first language acquisition. 